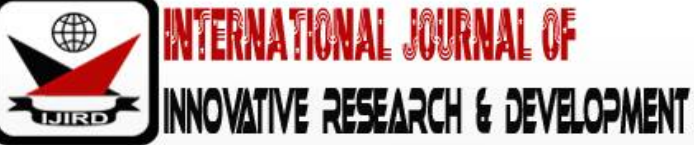

ISSN 2278 - 0211 (Online)

\section{Histological Effects of Ethanolic Stem Bark Extract of Anacardium Occidentale on the Kidney of Rabbits}

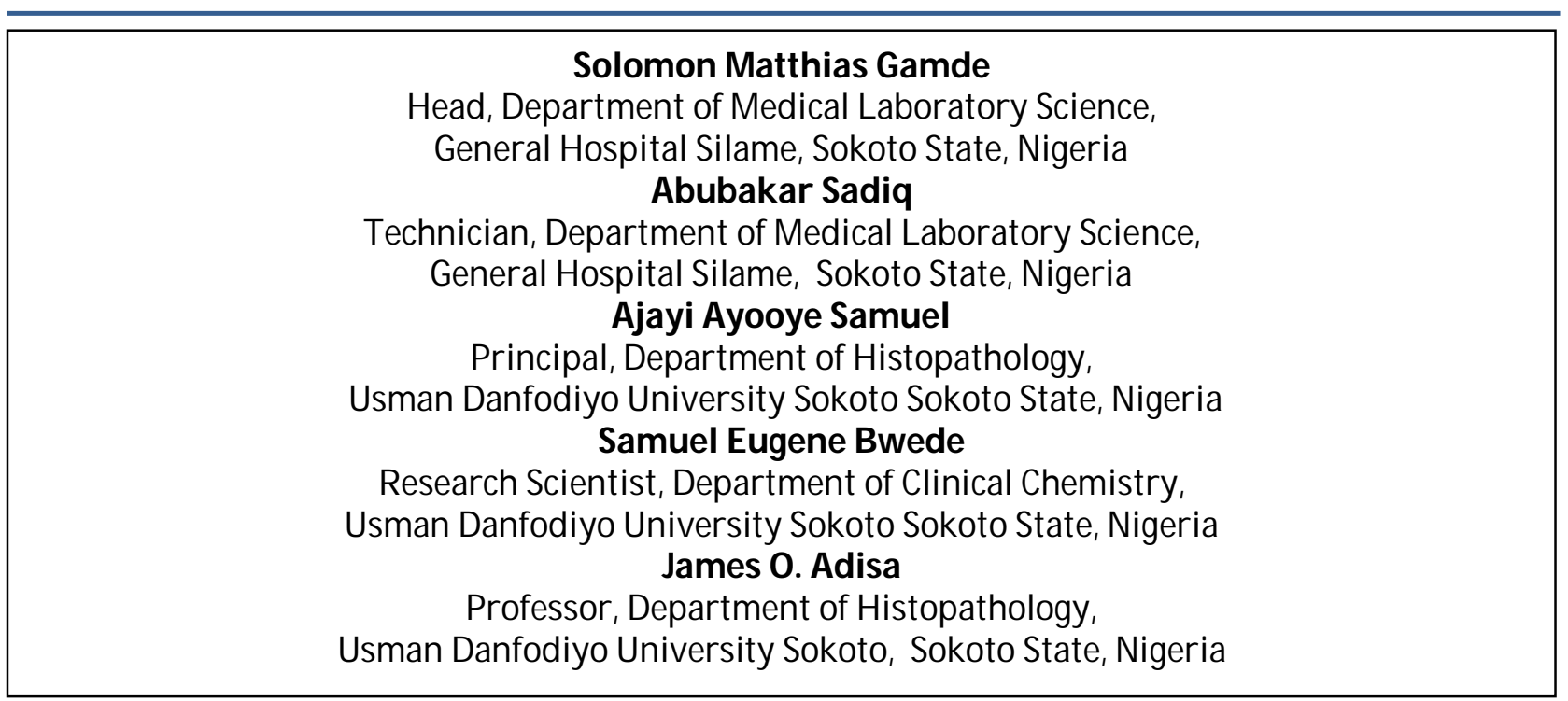

\begin{abstract}
The use of extracts of medicinal plants for treatments or prevention of diseases is a common health practice in most African societies. Anacardiumoccidentale is by far the most important flowering plant of the anacardiaceae family with great ethnomedicinal importance to third world countries including Nigeria, Brazil, India and Philippines. Traditionally, extracts of Anacardiumocciden tale are used as anti-diabetic, antibacterial, anti-inflammatory and antihypertensive agents. Base on disparities in the toxicological reports on the plant, this research seeks to evaluate the possible histological effect of ethanolic stem bark extract of the plant on the kidneys which are major excretory organs of metabolic products. Fourteen newly waned rabbits were divided into four groups of three animals each. Group 1 is negative control. Extract administered to groups (II, III and IV) at 500,1000 and $1500 \mathrm{mg} / \mathrm{kg}$ showed congested Glomerular Tufts devoid of urinary space. Hence, the cellular compartments are vulnerable to damage. Chronic toxicity studies are needed to further support the safety use of this plant for treatments.
\end{abstract}

Keywords: Anacardium occidentale, stem bark extract, ethanol, rabbit, congested glomerular tufts

\section{Introduction}

The use of extracts of medicinal plants for treatments or prevention of diseases is a common health practice in most African societies [1]. According to reports, medicinal plants are frequently considered less toxic and free from side effects than most synthetic drugs $[2,3,4]$. However, the safety of most herbal remedies is still doubtful although some have been validated through scientific research and clinical studies [5,6].

Anacardiumoccidentale (Cashew) is by far the most important flowering plant of the anacardiaceae family which consists of 73 genera and about 600 species [7]. Anacardium occidentale is native to the Portuguese in the colonial era and has spread widely with great economic importance to third world countries including Nigeria, Brazil, India and Philippines [8]. Due to it ethno-medicinal importance, there isgrowing interest in several countries especially with multiple uses of its different parts [9]. Traditionally, extracts of Anacardium occidentaleis used as an anti-diabetic, antibacterial, antiinflammatory and antihypertensive agents [10]. The leaves and stem bark are used for treatment of eczema, psoriasis, scrofula, dyspepsia, genital problems, and venereal diseases, as well as for impotence, bronchitis, cough, intestinal colic, leishmaniasis, and syphilis-related skin disorders [11]. Phytochemical studies produced evidence that extract of the plant contains bioactive components like tannins, alkaloids, glycosides, phenols, resins and carbohydrate flavonoids and alkaloid demonstrates gastro-protective functions. The bark and leaves are rich source of tannins, demonstrated anti-inflammatory and astringent properties, effective in treating diarrhoea [12]. Several clinical studies reported that itsphytochemicals curb darkening effect of aging by inhibiting tyrosinase and are toxic to certain cancerous cells [13]. However, the toxicological assessment of the plant demonstrated somearchitectural distortions of hepatic cells of animal tissues[14] and Intrauterine 
Growth Retardation (IUGR)in experimental animals indicating toxicity of the plant [15]. These reports were contrary to other findings on the safety of extracts of Anacardium occidentale[10,16,17]. Base on disparities in the toxicological reports on the plant, this research seeks to evaluate it possible histological effect on the kidneys which are major excretory organs of metabolic products.

\section{Materials and Methods}

\subsection{Extract Preparation}

Fresh samples of Anacardium occident tale stem-bark was collected May, 2013 at Lamingo, Jos North Plateau State, Nigeria. Botanical identification of plant was done at the herbarium unit of the Department of Plant Science, University of Jos. The fresh stem-bark was air dried at room temperature for two weeks and pulverized with pestle and mortar. $100 \mathrm{~g}$ of the coarse powder was macerated in 70\% ethanol and mixture was left for 48 hours, then mixture was filtered and concentrated in a vacuum at $20^{\circ} \mathrm{C}$ to yield dark brown extract [18]. Extract was transferred into a sample container and stored in desiccators. Dried extract was weighed and the percentage yield determined.

\subsection{Phytochemical Of Prospective Extracts}

The identification of chemical classes present in extracts of Anacardium occidentale, according to Matos method [19], is based on the observation of color change or formation of precipitate after the addition of specific reagents.

\subsection{Experimental Animals}

Fourteen (14) newly weaned rabbits purchased from the animal house and NVRI, VOM, were bred in the animal house of the Department of Pharmacy, University of Jos. The Rabbits were housed and maintained under standard conditions (12 hours' light and dark cycles). Food (pellet feeds and clean water) was administered ad libitum. The animals were cared for in accordance with the recommendations provided in the Guide for the Care and Use of Laboratory Animals prepared by the National Academy of Science (NIH, 1985).

\subsection{Experimental Design}

A total of 14 newly waned rabbits were used in this experiment. The animals were randomly divided into four groups of three each $(\mathrm{n}=3)$. Group I served as negative control, Group II (LD) received $500 \mathrm{mg} / \mathrm{kg}$, Group III (PD) prescribed dose was $1000 \mathrm{mg} / \mathrm{kg}$ and Group IV (HD) is highest dose $(1500 \mathrm{mg} / \mathrm{kg})$. Body weights of the animals were obtained using weighing scale (Adventurer Model Item No: Arc 120).

\section{Results}

Phytochemical screening of ethanolic stems bark extract of Anacardium occidentale revealed the presence of carbohydrate, steroids, flavonoid, tannins and terpenes (Table 1).

\begin{tabular}{|c|c|c|c|}
\hline S/ N & Phytochemicals & Present or Absent & Concentration \\
\hline 1. & Alkaloids & Absent & \\
\hline 2. & Saponins & Absent & + \\
\hline 3 & Tannins & Present & +1 \\
\hline 4 & Carbohydrates & Present & ++ \\
\hline 5 & Flavonoids & Present & +1 \\
\hline 6 & Steroids & Present & \\
\hline 7 & Cardiac Glycosides & Absent & \\
\hline 8 & Anthroquinones & Absent & \\
\hline
\end{tabular}

Table 1: Quantitative Phytochemical Screening of Ethanolic

Stem Bark Extract of Anacardium occidentale

Keys: ++ High ++ Very High

The overall percentage yield of the extract was calculated using the formula below;

Percentage yield of extract $\quad=\quad$ Mass of Extract $\quad$ X 100

Percentage yield

Mass of Raw Tree Bark Loaded

$\frac{38 \mathrm{~g}}{100 \mathrm{~g}} 100$

$\begin{array}{ll}= & \frac{38 \mathrm{gx}}{100 \mathrm{~g}} \\ = & 38 \%\end{array}$

3.1. General Observations Following 14 Days Oral Exposure of Ethanolic Stem Bark Extract of Anacardium Occidentale

No mortality in the negative control group while mortality in groups orally exposed to the extract recorded significant mortality in dose depend rate (Table 2). 


\begin{tabular}{|c|c|c|c|c|c|c|c|}
\hline \multirow[b]{2}{*}{ Groups } & \multirow[b]{2}{*}{$\begin{array}{c}\text { Treatment } \\
(\mathrm{Mg} / \mathrm{Kg})\end{array}$} & \multirow{2}{*}{$\begin{array}{c}\text { Number of } \\
\text { Rabbits } \\
\text { used }\end{array}$} & \multirow[b]{2}{*}{$\begin{array}{c}\text { Week } \\
1 \\
\text { Dead } \\
\end{array}$} & \multirow[b]{2}{*}{ \% Mortality } & \multicolumn{3}{|c|}{ Number of Dead Rabbits } \\
\hline & & & & & $\begin{array}{c}\text { Week } \\
2 \\
\text { Dead }\end{array}$ & $\begin{array}{c}\% \\
\text { Mortality }\end{array}$ & Sacrificed \\
\hline i. & Control & 3 & 0 & 0 & 0 & 0 & 3 \\
\hline ii. & LD (500mg/ kg) & 3 & 0 & 0 & 2 & 66.7 & 1 \\
\hline iii. & $\mathrm{PD}(1000 \mathrm{mg} / \mathrm{kg})$ & 3 & 0 & 0 & 2 & 66.7 & 1 \\
\hline iv. & $\mathrm{HD}(1500 \mathrm{mg} / \mathrm{kg})$ & 3 & 2 & 66.7 & 0 & 0 & 1 \\
\hline
\end{tabular}

Table 2: Percentage Mortality Following 14 Days Oral Exposure of

Rabbits to Ethanolic Stem Bark Extract of Anacardium Occidentale and Negative Control ( $N=14)$

$\%$ Mortality

$\begin{array}{ll}= & \text { No. of Dead Rabbits X } 100 \\ = & \frac{2}{2} \text { Xotal No. of Rabbits } \\ = & 66.7 \%\end{array}$

Keys:

$\mathrm{CN}$ - Control

$\mathrm{HD}$ - High dose

LD - Low dose

PD - Prescribed Dose

\begin{tabular}{|c|c|c|}
\hline Groups & Treatments & Physiological and behavioral Observations \\
\hline I & Control (Distil Water) & $\begin{array}{c}\text { Smooth fur appearance, semi formed droppings, Amber } \\
\text { color urine, Rabbits active }\end{array}$ \\
\hline ii. & $\mathrm{LD}(500 \mathrm{mg} / \mathrm{kg})$ & $\begin{array}{c}\text { Smooth fur appearance, semi formed droppings, Amber } \\
\text { color urine, Rabbits very active }\end{array}$ \\
\hline iii. & $\mathrm{PD}(1000 \mathrm{mg} / \mathrm{kg})$ & $\begin{array}{c}\text { Rough fur appearance, watery droppings, dark colored } \\
\text { urine, Rabbits very weak with enlarged abdomen }\end{array}$ \\
\hline iv. & $\mathrm{HD}(1500 \mathrm{mg} / \mathrm{kg})$ & $\begin{array}{c}\text { Rough fur appearance, watery dropping, dark brown urine, } \\
\text { Rabbits very weak with enlarged abdomen. }\end{array}$ \\
\hline
\end{tabular}

Table 3: Physiological and Behavioural Observations Following 14 Days Oral Exposure of Rabbits to Ethanolic Stem Bark Extract of Anacardium Occidentale( $\mathrm{N}=9)$

\begin{tabular}{|c|c|c|c|c|c|c|c|}
\hline S/n & $\begin{array}{c}\text { Treatment group } \\
\mathbf{( m g / / k g )}\end{array}$ & $\begin{array}{c}\text { Week 1 } \\
\text { Food } \\
\text { intake (kg) }\end{array}$ & $\begin{array}{c}\text { Week 2 } \\
\text { Food } \\
\text { intake (kg) }\end{array}$ & Remark & $\begin{array}{c}\text { Week 1 } \\
\text { Water } \\
\text { intake (ml) }\end{array}$ & $\begin{array}{c}\text { Week 2 } \\
\text { Water } \\
\text { intake (ml) }\end{array}$ & Remark \\
\hline i. & Control & 0.06 & 0.046 & Increase & 140.00 & 150.00 & Increase \\
\hline ii. & LD (500mg/ kg) & 0.031 & 0.054 & Increase & 84.30 & 90.00 & Decrease \\
\hline iii. & PD (1000mg/ kg) & 0.03 & 0.019 & Decrease & 90.95 & 52.20 & Decrease \\
& & & & & & & \\
\hline iv. & HD (1500mg/kg) & 0.008 & 0.00 & Decrease & 0.00 & 0.00 & None \\
\hline
\end{tabular}

Table 4: Showing Food and Water Intake Following 14 Days Oral Exposure of Rabbits to Ethanolic Stem Bark Extract of Anacardium Occidentaleand Negative Control (N=14)

3.2.Histological Findings Following 14 Days Oral Exposure of Rabbits to Ethanolic Stem Bark Extract of Anacardium Occidentale And Negative Control Group ( $\mathrm{N}=14)$

Histological section of kidney (control group) shows normal renal cortex (RC), Bowman's capsule (BC), within is blood cells and a well-defined Basement membrane with supporting tissue. Magnification x400

Sections of kidney $(500 \mathrm{mg} / \mathrm{kg})$ show renal cortex $(\mathrm{RC})$ with section of the Bowman's capsule (BC) containing trapped red blood cells and lymphocytes. The urinary space is minimal. Around the BC are sections of renal tubules and a large blood clot within a vessel. Magnification x400 
Section of kidney $(1500 \mathrm{mg} / \mathrm{kg}$ ) show renal cortex (RC) with an evidently congested Glomerular Tuft (GT) completely devoid of urinary space and with two dilated Capillaries (C). Around these are supporting tissue and congested renal tubules with their lumen narrowed. Magnification x400

Section of kidney $(1500 \mathrm{mg} / \mathrm{kg})$ show glomerular tuft (GT) with trapped blood cells that is surrounded by urinary space (U) appears slightly enlarged between the glomerulus and the basement membrane when compared to the control. Around the Bowman's capsule are sections of renal tubules (T). Magnification x400

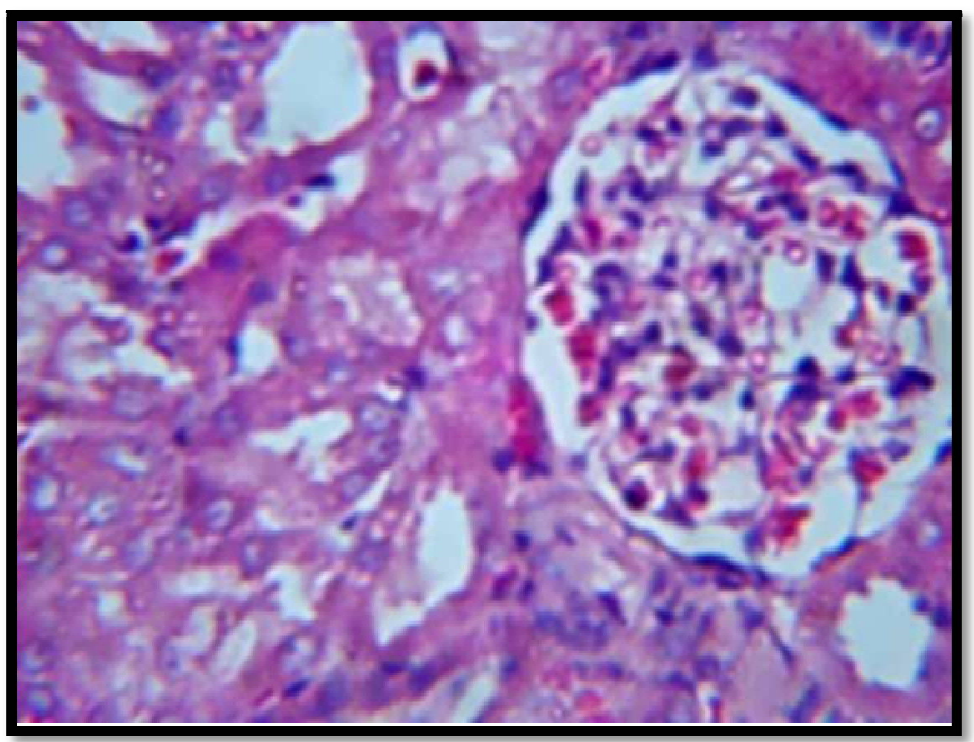

Figure1: Histological Section of Kidney (Control Group) Shows Normal Renal Cortex (RC), Bowman's Capsule (BC), Within Is Blood Cells and a Well-Defined Basement Membrane with Supporting Tissue, Magnification X400

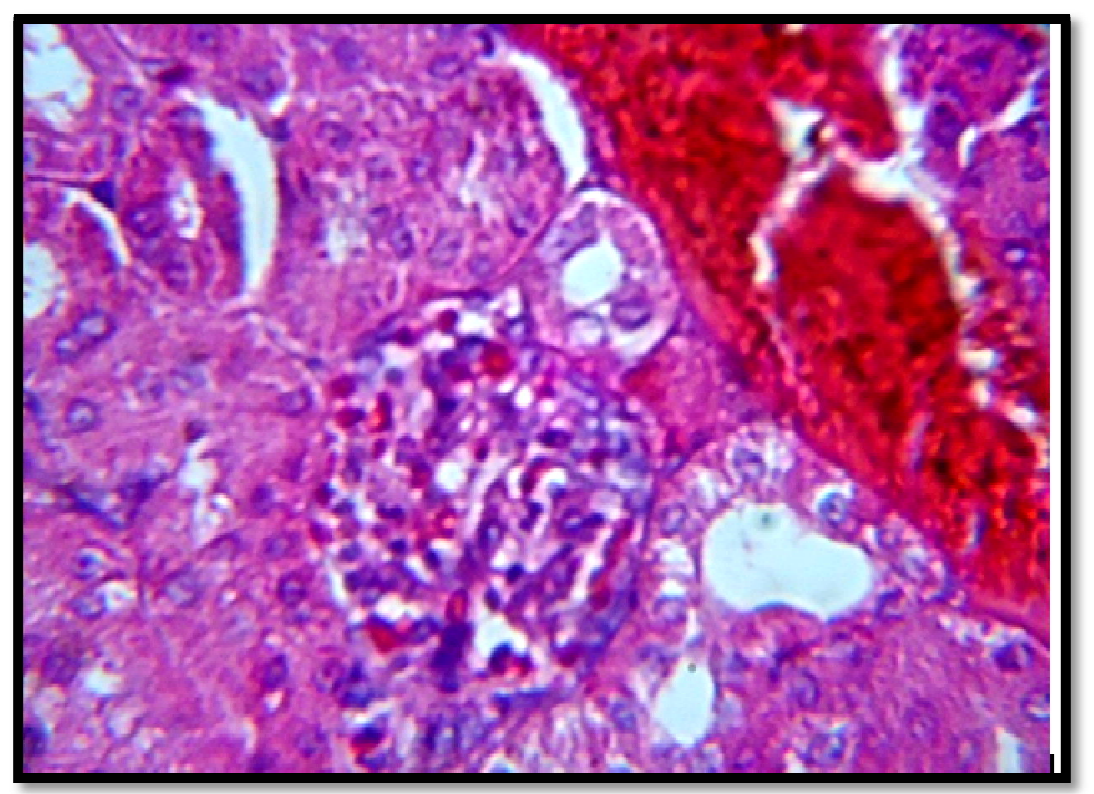

Figure 2: Sections of Kidney (500mg/ Kg) Show Renal Cortex (RC) with Section of the Bowman's Capsule (BC) Containing Trapped Red Blood Cells and Lymphocytes. The Urinary Space Is Minimal. Around The BC Are Sections of Renal Tubules and a Large Blood Clot within a Vessel, Magnification X 400 


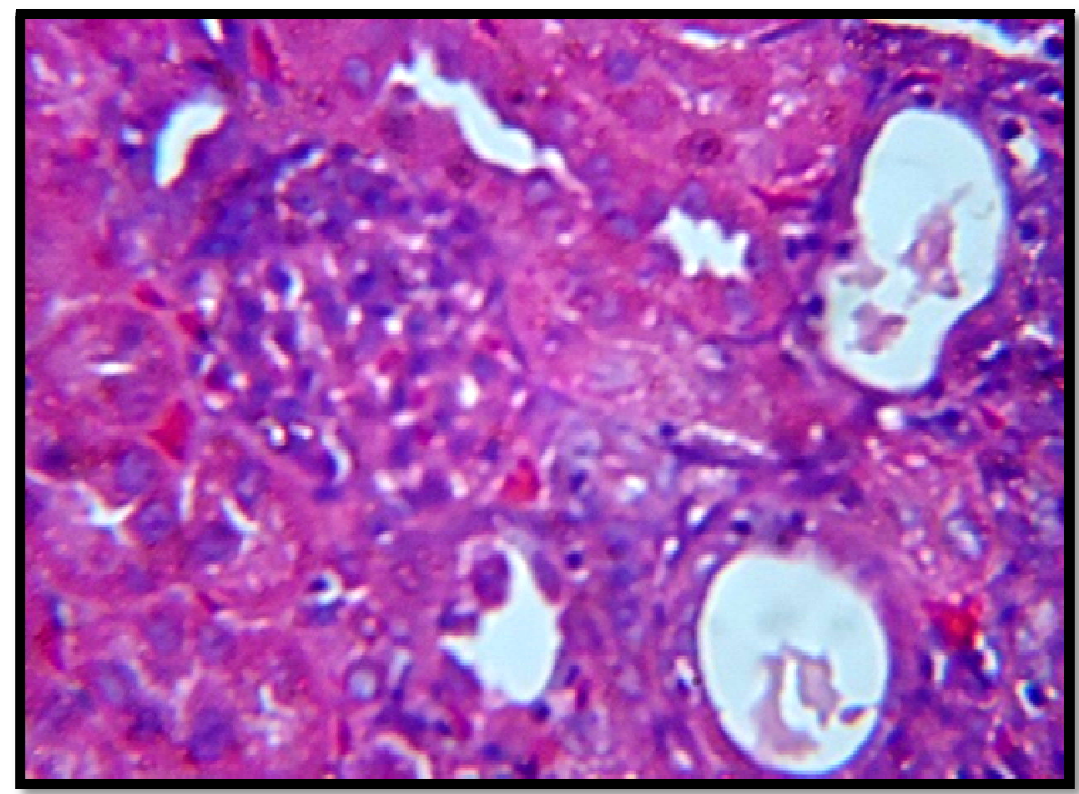

Figure 3: Section of Kidney (1500mg/ Kg) Show Renal Cortex (RC) with an Evidently Congested Glomerular Tuft (GT) Completely Devoid Of Urinary

Space and with Two Dilated Capillaries (C), around These Are Supporting Tissue and Congested Renal Tubules with Their Lumen Narrowed Magnification X400

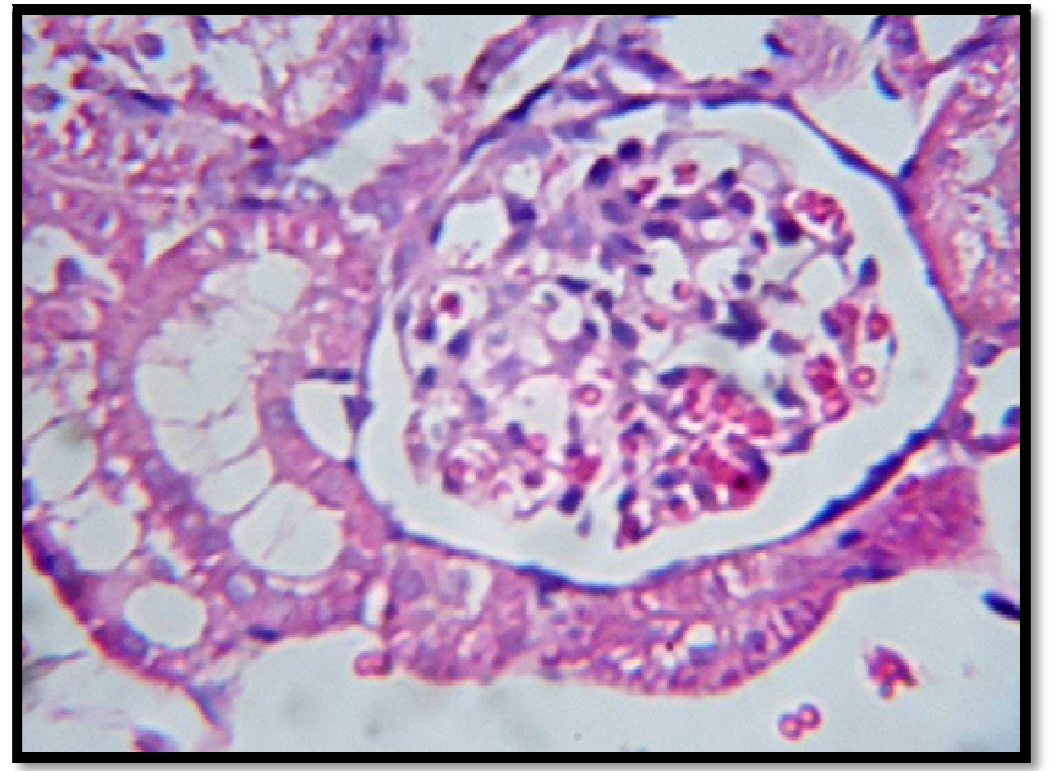

Figure 4: Section of Kidney (1500mg/ Kg) Show Glomerular Tuft (GT) with Trapped Blood Cells That Is Surrounded By Urinary Space (U) Appears Slightly Enlarged Between the Glomerulus and the Basement Membrane When Compared to the Control, around the Bowman's Capsule Are Sections of Renal Tubules (T), Magnification X400

\section{Discussion}

The phytochemical analysis of ethanolic stem bark extract of Anacardium occidentale reveals the presence of flavonoids, Tannins, Steroids and carbohydrates similar to Oyemosi et al. (2011) report. These phytochemicals are reported by several researches to improve and maintain health [20]. However, Flavonoids causes capillary fragility and inhibit platelet aggregation. These properties could be responsible for the haemorrhage seen in all treated groups of Rabbits (Plates B, C, D). Flavonoids are also powerful antioxidant and free radical scavengers. Some flavonoids are used directly as toxins which could be responsible for the observed mortality in all treated groups [21].The bitter property of tannins could contribute like flavonoids to the reduced food and water intake of animals group treated with aqueous extract (Tables 2,4). Astringent property of tannins could also be responsible for the enlarged abdomen of the Animals (Table 3).

Steroids are effectively used to relief severe colitis and as enemas [21], could be responsible for the watery and frequent droppings observed in the Prescribed and High treatment groups (Table 3). Carbohydrates are rich source of energy giving food. It has 4kcalories of energy. This could be responsible for the alertness observed in the low dose, although it should be expected that Prescribed and High treatment groups have more calories and therefore increased 
alertness but that was not observed. It is very obvious that other phytochemicals like flavonoids and tannins combined effects as observed in the first and second paragraphs interfered and counteracted the beneficial effects of carbohydrate (Table 3).

Histological sections of kidneys showed several morphological changes compared with negative control. FIGURE 1 shows a normal kidney with renal cortex intact and squamous epithelium of the parietal layer. Figure 2 shows Bowman's capsule with trapped red blood cells and lymphocytes. Figure 3 shows evidently congested glomerular tuft completely devoid of urinary space and with dilated capillaries. And Figure 4 is showing glomerular tufts with trapped red blood cells and lymphocytes surrounded by the urinary space which appears slightly enlarged between the glomerulus and the basement membrane when compared to the control. The histological sections of low dose and prescribed dose show some hemorrhagic capillaries (C). This hemorrhage resulted from the extravasion of blood into the extra vascular space. Capillary bleeding could occur under conditions of chronic congestion and increased tendency to hemorrhage could also result from diverse clinical disorders, collectively called hemorrhagic diathesis. All these clinical features are classical effects described in the uses and properties of citrus flavonoids [21]. These findings are in agreement with the extract toxicity reported by Awe [14] and Dare [15] respectively. Similarly, kidney lesions were observed on $1000 \mathrm{mg} / \mathrm{kg}$ treated rats following oral sub-acute treatment with Acanthusmontanus aqueous leaves extract [23]. However, this finding is contrary to other reports of the stem bark extracts of the plant to be non-toxic on the kidney $[11,16,18,24]$.

\section{Conclusion}

Histological effects following 14 days Oral Exposure of Rabbits to Ethanolic Stem Bark Extract of Anacardium occidentale revealed reduced food and water intake of the animals treated with extract. High mortality rate that is dose dependent in all treated animals compare to control. Histopathological findings show evidently trapped red blood cells and lymphocytes in the Bowman's capsule with minimal urinary space. In large dose, the congested urinary space is devoid of urinary space. Hence, chronic toxicity studies are needed to further support the safety use of this plant for treatments.

\section{References}

i. Idakwoji Precious Adejoh, Ajima Judith Nnedimkpa, Anosike Joy Chizoba, Amadi Emenike Benjamin and NwejeAnyalowu Paul Chukwuemeka (2018). Effects of Aqueous Stem Bark Extract of Citrus aurantifolia on the Gastrointestinal Tract of Wistar Rats, Asian Journal of Research in Medical and Pharmaceutical Sciences, 5(3): 1-7, 2018.

ii. Lucija Kuna, Jelena Jakab, Robert Smolic, Nikola Raguz-Lucic, Aleksandar Vcev and Martina Smolic (2019). Peptic Ulcer Disease: A Brief Review of Conventional Therapy and Herbal Treatment Options. Journal of Clinical Medicine, 8, 179:1-19.

iii. Pahadiya Anitakumari Rambhai, S. S Sisodia (2018). Indian Medicinal Plants for Treatment of Ulcer: Systematic Review, UK Journal of Pharmaceutical and Biosciences, 6(6): 38-44.

iv. Nishu Khera and Aruna Bhatia (2014). Medicinal Plants as Natural Anti-Diabetic Agents. International Journal of Pharmaceutical Science and Research, Vol. 5(3): 713-729.

v. Ekor Martins, Luisa Pistelli, Zemede Asfaw, Susan Sempele (2014). The Growing Uses of Herbal Medicines: Issues Relating to Adverse Reactions and Challenges in Monitoring Safety. Frontiers in Pharmacology. 4:4-6.

vi. Angel Josabad Alonso-Castro, Fabiola Domínguez, Alan Joel Ruiz-Padilla, Nimsi Campos-Xolalpa, Juan Ramón Zapata-Morales, Candy Carranza-Alvarez, and Juan Jose Maldonado-Miranda (2017). Review Article; Medicinal Plants from North and Central America and the Caribbean Considered Toxic for Humans. Hindawi Evidence Based Complementary and Alternative Medicine.2:1-28.

vii. Dare SS, Hamman WO, Musa S, Goji ADT, Oyewale AA, Abba S, Ezekiel I (2011). Effects of Aqueous Extract of Anacardium occidentale (Cashew) Leaf on Pregnancy Outcome of Wistar Rats. International Journal of Animal Vet nary Advances, 3(2):77-82.

viii. Adeigbe O.O, Olasupo F.O, Adewale B.D, Muyiwa A.A (2015). A Review on Cashew Research and Production in Nigeria for the past four Decades, Academic Journal of Scientific Research and Assays, Vol.10(5):196-209.

ix. Okogbaa J, Akomolafe G, Terna T, Kwon-Ndung H, Amaobi H (2018). Preliminary Botanical Assessment of Production Challenges of Cashew (Anacardium occidentale) in Lafia, Nasarawa State, Nigeria. Vol. 8: 26-31.

x. Arokoyo DS, Bamidele O, Babatunde L, Adebisi O (2015). Haemostatic Effect of Methanolic Stem Bark Extract of Anacardiumoccidentale inMale Albino Rats. Journal of Medicine and Medical Sciences,Vol. 6(3): 58-65.

xi. Godfrey innocent iyare, Nosa Terry Omorondion, Theophilus Ogie Erameh, Peter Uwadiegwu Achukwu, Anaziah Grace Ogochukwu (2017).MOJ Biology and Medicine, Volume 2 (2): 2-6.

xii. Laurens AC (1999). Screening of some Medicinal Plants for Antimicrobial Activity. Journal of Ethnopharmacy, Vol.67(2): 225-228.

xiii. Kubo K, Akima H, Kouzaki M, Ito M, Kawakami Y (2000). Changes in the elastic properties of tendon structures following 20 days bed rest. European Journal of Applied Physiology, 83(6): 463-468.

xiv. Awe S, Sani A, Eniola K, Kayode R (2013). Toxicological Assessment of Locally Produced Cashew Wine. International Journal of Recent Research and Applied Studies, 15(1):125- 131.

xv. Pond, S.M., 1996. Medicine in Pregnancy. 1st Edn., Australian Government Publishing Service. Canberra, Australia.

xvi. Adepoju E.A, Ajileye A.B, Fasogbon S.A (2015). The Effect of Aqueous Extract of AnacardiumOccidentale Stem Back on the Histology of The Testes of Adult Wistar Rat. African Journal of Cellular Pathology, 5:36-39. 
xvii. Obembe 0.o, Ige A.O (2016). Sperm parameters of male Wistar rats treated with Anacardium occidentale L. leaf extract. Research Journal of Health Science, Vol. 4(1):83-89.

xviii. Oyemosi Tajuden, Oyesina AJAO and Moyosore Salihu (2011).Histological Effect of Aqueous Extract of Anacardium occidentale Stem Bark on Adult Wistar Rat Testis. Medical practiceand Review. 2(7):73-77.

xix. Matos FJA (1997). Introdução à fitoquímica experimental. UFC Edições. pp. 44-46.

xx. Newall A. Carol, Linda A. Anderson and David J. Philipson (1996). Herbal uses. Herbal Medicine, Guide for Health Care Professionals. 1 ed., Pharmaceutical Press, London. Pp. 21-286.

xxi. Obdulio Benavente, Julian Castillo, Francisco R, Ana Ortuno and Jose Rio (1997). Uses and Properties of Citrus Flavonoids. Journal of Agricultural and Food Chemistry. Ref No: 970373s. Pp. 4505-4515.

xxii. Walter Model (1976-1977). Drugs for Gastrointestinal Diseases by Herbert Rakatansky and Joseph Kirsner. Drugs of Choice. 1976 ed. Mosby Company. Saint Louis. Pp. 338-339.

xxiii. Djami Tchatchou Arnaud Thierry, Asongalem Emmanuel Acha, Nana Paulin, Choumessi Aphrodite, Kamtchouing Pierre, Asonganyi Tazoacha (2011). Subacute Toxicity Study of the Aqueous Extract from Acanthus montanus. Electronic Journal of Biology, 7(1): 11-15.

xxiv. Adou M, Kouassi DA, Tetchi FA, Amani NG (2011a). Phenolic Profile of cashew Apple Juice (Anacardium occidentale) from Yamoussoukro and Korhogo (Côte d"Ivoire). Journal of Applied Bioscience, 49:3331-3338. 